\title{
MODELING STRUCTURE OF Glucose-6-phosphate dehydrogenase FROM Leuconostoc mesenteroides STRAIN K
}

\author{
H. Hidayat ${ }^{1,2}$, W. Haryadi ${ }^{1}$ and T.J. Raharjo ${ }^{1, 凶}$ \\ ${ }^{1}$ Department of Chemistry, Faculty of Mathematic and Natural Sciences, Universitas \\ Gadjah Mada, Jl. Sekip Utara 15, Yogyakarta 55720, Indonesia \\ ${ }^{2}$ Department of Chemistry, Faculty of Mathematic and Natural Sciences, Universitas Islam \\ Indonesia, Jl. Kaliurang Km 14,5 Yogyakarta 55584, Indonesia \\ ${ }^{\square}$ Corresponding Author: trijr_mipa@ugm.ac.id; habibihidayat13@uii.ac.id
}

\begin{abstract}
Glucose 6-phosphate dehydrogenase is one of many enzymes found in Lactic Acid Bacteria (LAB). Leuconostoc mesenteroides strain K7 has been isolated from Kelengkeng (Dimocarpus longan) fruit. Kelengkeng fruit can generate $\mathrm{LAB}$ in previous research. The type of microbial isolate in form of the acidophilic microbe with pH 2.0 till 5.0 and it has macroscopic and microscopic characteristics is LAB and able to generate antimicrobial activity. The amplification results of the PCR technique showed glucose 6-phosphate dehydrogenase gene from L. mesenteroides strain K7 of $1112 \mathrm{pb}$ as glucose-6-phosphate dehydrogenase (L. suionicum) with a similarity percentage of 99.41\%. The modeling structure with SWISS-MODEL server was obtained of 486 amino acids with MSA analysis result of target protein sequence was LTGGGDKANDDAVEDDANNSATDAS FLADGTNSATMPSKA. It means that the sample variance is very significant and protein database to glucose-6-phosphate-1-dehydrogenase. The 3D modeling predictions of sequence identification results from target protein isolate and template (1h9a.1.A) have a similarity of $91.55 \%$ by glucose 6-phosphate dehydrogenase.
\end{abstract}

Keywords: Leuconostoc, Glucose 6-phosphate, Dehydrogenase, Swiss-Model, Three-dimensional

RASĀYAN J. Chem., Vol. 14, No.4, 2021

\section{INTRODUCTION}

High biodiversity provides a great opportunity to get potential microorganisms to be developed as a producer of the enzyme glucose 6-phosphate dehydrogenase that needs to be done. ${ }^{1}$ One of the potential microorganisms is Leuconostoc mesenteroides strain $\mathrm{K} 7$ which is derived from Kelengkeng pulp. Lactic acid bacteria (LAB) have probiotics properties. ${ }^{2}$ The enzymes are very important because it has an important role in the pentose phosphate pathway to produce NADPH and ribose phosphate molecules. Glucose 6-phosphate dehydrogenase (G6PD) is the limiting enzyme of the pentose phosphate pathway (PPP) correlated to cancer progression and drug resistance. ${ }^{3}$ However, it's also an enzyme needed in the oxidation process of glucose molecules through the pentose phosphate (Hexoxe mono phosphate shunt (HMP shunt) pathway which is useful for oxidizing glucose-6-phosphate to 6-phosphoglucono-D-lactone. NADPH has an important role in the reductive synthesis of several metabolic processes, including the synthesis of fatty acids, steroids, amino acids through glutamate dehydrogenase, and reduced glutathione (GSH). Meanwhile, ribose phosphate is important in the process of forming nucleic acids such as DNA and RNA. One glutathione is a peptide consisting of three amino acid molecules, namely the amino acid glutamate, cysteine, and glycine.

Many of these microorganisms are produced by lactic acid bacteria. Enzymes produced by LAB, among others; three-dimensional structure modeling of a protease from lactic acid bacteria Leuconostoc mesenteroides $\mathrm{K} 7$ using automated protein homology analysis ${ }^{4,5}$ with SWISS-MODEL Program. ${ }^{6}$ Until now, the enzyme that produces lactic acid bacteria has not been carried out. So that the related information is still very little.

Lactic Acid Bacteria can perform anaerobic metabolic processes as Generally Recognized as Safe (GRAS) ${ }^{7}$ in the food industry. ${ }^{8}$ This anaerobic metabolic process converts carbohydrates into energy in the absence of oxygen. 
One of the anaerobic carbohydrate metabolic processes is glucose 6-phosphate dehydrogenase. Anaerobic organisms contain the glucose 6-phosphate dehydrogenase gene which is expressed strongly enough that it is often used as a housekeeping gene in the LAB gene expression test. The presence of a gene can be characterized by amplifying the gene using PCR techniques and then sequencing the target. The functional structure of a protein or enzyme is a Three-Dimensional (3D) structure. The determination of 3D structure is done with X-ray crystallography (XRC) against the protein using SWISS-MODEL can be used as an alternative that gives good results for the prediction structure.

\section{Material and Methods}

\section{EXPERIMENTAL}

The genomic DNA source of L. mesenteroides strains K7 isolated from Kelengkeng, Nutrient Agar (NA) (Sigma Aldrich), Nutrient Broth (NB) (Sigma Aldrich), DNA ladder 100 bp (Vivantis), Loading dye DNA, GoTaq Green Master Mix (Promega), nuclease-free water (NFW) (Gibco), Ethidium bromide (Sigma Aldrich), Primary design of glucose-6-phosphate dehydrogenase gene, namely DPF (5'ATTGTTGGGACAGCACGTCA-3') and DPR (5'-CCAAGTTGATTGTGCGGGTG-3'), PureLinkTM Quick Gel Extraction kit (Life Technologies), and BigDye X-terminator Kit (Applied Biosystem).

\section{Encoding of glucose-6-phosphate dehydrogenase Gene}

It must be prepared forward and reverse primers based on gene sequence glucose-6-phosphate dehydrogenase from Genebank (http://www.ncbi.nlm.nih.gov) with utilizing the bioinformatics online server especially blast primer (https://blast.ncbi.nlm.nih.gov/Blast.cgi). The primary criteria utilized were among others: length of DNA product is 1078 with a length of DNA primary design for each of 20 . The start and stop in position are 124 and 143 for forward and 1201 and 1182 for reverse. Tm value for forward and the reverse is 60.18 and 60.04 with GC\% for each being 50 and 55. Besides, self-complementarity size is 4.0 and 5.0 while self 3 ' complementarity is 1.0 and 0.0 . The PCR primers obtained used were synthesized at IDT DNA, Singapore.

\section{Amplification of bacterium gene using PCR}

The amplification process begins by preparing a sample of bacterium DNA isolate from Kelengkeng fruit isolation. PCR microtube containing a GoTag Green Master Mix was added $2 \mu \mathrm{L}$ for each primer that is 27F (5'-AGAGTTTGAATCCTGGCTCAG-3') and 1525R (5'-AAGGAGGTGA TCCA GCC-3') then 2

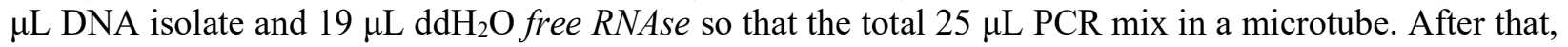
it's put into the PCR thermalcycler machine and reacted with the conditions were as follows: predenaturation at $95{ }^{\circ} \mathrm{C}$ for 5 min as many as 35 cycles. Each cycle consists of denaturation at $95{ }^{\circ} \mathrm{C}$ for 1 min, annealing at $52{ }^{\circ} \mathrm{C}$ for $1 \mathrm{~min}$, elongation at $72{ }^{\circ} \mathrm{C}$ for $1 \mathrm{~min}$, and final elongation at $72{ }^{\circ} \mathrm{C}$ for $5 \mathrm{~min}$. After that, the amplification product was analyzed using electrophoresis gel agarose $1.5 \%$ at 50 Volt for 75 min. The PCR product was produced as a template for the next PCR process.

The next PCR process after the sequence from the first PCR product is a part of glucose-6-phosphate dehydrogenase enzyme then matched with nucleotide from other organisms of genebank using Basic Local Alignment Search Tool Nucleotide (BLASTn) (http://blast.ncbi. nlm.nih.gov/Blast.cgi) online software. The gene sequence was analyzed in primary design from glucose-6-phosphate dehydrogenase gene and available primary design as follows: DPF (5'-ATTGTTGGGACAGCACGTCA-3') and DPR (5'CCAAGTTGATTGTGCGGGTG-3').

\section{DNA Sequencing Process}

The sequence of nucleotides sequenced with forward and reverse primers can be determined from the alignment results by using the Molecular Evolutionary Genetics Analysis X (MEGAX) program. The gene sequence of glucose-6-phosphate dehydrogenase enzyme then matched with nucleotides from other organisms in genebank using Basic Local Alignment Search Tool Nucleotide (BLASTn) (http://blast.ncbi. nlm.nih.gov/Blast.cgi) online software. The results obtained were then analyzed for their similarity to the gene of glucose-6-phosphate dehydrogenase enzyme from L. mesenteroides bacterium utilizing CLUSTAL W2 (https://www.ebi.ac.uk/Tools/msa/clustalw2/) online software. 
RASĀYAN $J$. Chem.

Vol. 14 | No. 4 |2613-2621| October- December | 2021

\section{Modeling Structure of Glucose-6-phosphate dehydrogenase}

The glucose-6-phosphate dehydrogenase sequence is translated into an amino acid sequence using the ExPASy translation (http://web.expasy.org/translate/) program to do ORF predictions. The selected ORF is compared once more with genebank database using the Basic Local Alignment Search Tool Protein (BLASTp) (https://blast.ncbi.nlm.nih. gov/Blast.cgi) program. To gain structural insight, the alignment of many amino acid sequences is performed using the Conseq server (http://consurf.tau.ac. i1/2016/). The parameters used by MSA are as follows: the homology search algorithm is CSI-BLAST with a number of literations of 3 and a cutoff E-value of 0.0001; the protein database is UNIREF-90; the alignment method is MAFFT-L-INS-i.30. After that, SWISS-MODEL (https://swissmodel.expasy.org/) using to predict 3D modeling of protein structure by entering amino acid sequence data in the same way in the star a new modeling project (https://swissmodel.expasy.org/interactive) Table.

\section{RESULTS AND DISCUSSION}

One of the characteristics of LAB is the presence of a gene coding for glucose 6-phosphate dehydrogenase. The glucose 6-phosphate dehydrogenase generated through the EMP pathway turns into pyruvic acid and finally, the lactate dehydrogenase enzyme converts pyruvic acid into lactate, it is necessary glucose 6phosphate dehydrogenase gene in the process ${ }^{9}$. Further confirmation of the K7 isolate as LAB was carried out by looking at the present glucose 6-phosphate dehydrogenase gene in the bacterium. Characterization of the gene in $\mathrm{K} 7$ isolate is also intended to know the potential of the bacterium as a source of glucose 6phosphate dehydrogenase enzyme production through gene sequences. The PCR technique was used to amplify the target gene by sequencing the gene sequence. The primary design used to characterize the gene is based on the intact of the genes from L. mesenteroides bacterium obtained from the genebank (http://www.ncbi.nlm.nih.gov). The primary design is done using primer blast online software with parameters as follows: length of DNA product above $500 \mathrm{pb}$, primary length of at least $20 \mathrm{pb}$, GC content above $50 \%$ and not a self-complement to avoid primary dimers.

The five pairs of primers that are obtained and selected, the number pairs that have sequences are DPF (5'ATTGTTGGGACAGCACGTCA-3') and DPR (5'-CCAAGTTGATTG TGCGGGTG-3') which has an amplification target of $1078 \mathrm{pb}$ at $124-1201 \mathrm{pb}$ (Table-1). The forward and reverse positions at 124-143 and 1201-1182 respectively. The Tm of forward and reverse are 60.18 and 60.04 with GC content of 50\% and $55 \%$ respectively. This primary pair was chosen based on several requirements, namely: primer has a large amplicon, primary length, melting point (Tm), and does not form a secondary structure such as selfdimers, cross dimers or hairpins. Good primers have a condition, among others: having an oligonucleotide base length between 18-24 bases, has a specific base sequence to attach printed DNA, there are no complementary bases at 3' end so there is a dimer, base composition to cytosine and guanine of $50 \%$ from all bases, and two paired primers have not much different Tm. ${ }^{10}$

Table-1: The Primary Design Result of the glucose 6-phosphate dehydrogenase gene

\begin{tabular}{c|l|l|c|c|c}
\hline No & \multicolumn{1}{|c|}{ Sequences } & $\begin{array}{c}\text { Position on } \\
\text { Template } \\
\text { Gene }\end{array}$ & $\begin{array}{c}\text { Target } \\
\text { Size }\end{array}$ & $\%$ GC & Tm \\
\hline 1. & $\begin{array}{l}\text { Sequence (5'-3') } \\
\text { Forward primer: } \\
\text { ATTGTTGGGACAGCACGTCA } \\
\text { Reverse primer: } \\
\text { CCAAGTTGATTGTGCGGGTG }\end{array}$ & $\begin{array}{l}\text { Start 124 } \\
\text { Stop 143 } \\
\text { Start 1201 } \\
\text { Stop 1182 }\end{array}$ & 1078 & 50.00 & 60.18 \\
\hline 2. & $\begin{array}{l}\text { Sequence (5'-3') } \\
\text { Forward primer: } \\
\text { TGGGACAGCACGTCAACAAT } \\
\text { Reverse primer: } \\
\text { TCCAAGTTGATTGTGCGGGT }\end{array}$ & $\begin{array}{l}\text { Start 129 } \\
\text { Stop 148 } \\
\text { Start 1202 } \\
\text { Stop 1183 }\end{array}$ & 1074 & 50.00 & 60.04 \\
\hline 3. & $\begin{array}{l}\text { Sequence (5'-3') } \\
\text { Forward primer: } \\
\text { ATGTCAGTTGCCCCTCGTTT }\end{array}$ & $\begin{array}{l}\text { Start 349 } \\
\text { Stop 368 } \\
\text { Start 1348 }\end{array}$ & 1000 & 50.00 & 60.18 \\
\hline
\end{tabular}


RASĀYAN J. Chem.

Vol. 14 | No. 4 |2613-2621| October-December | 2021

\begin{tabular}{c|l|l|c|c|c}
\hline & $\begin{array}{l}\text { Reverse primer: } \\
\text { CGGCAGTAATTGCGTCAACA }\end{array}$ & Stop 1329 & & & \\
\hline 4. & $\begin{array}{l}\text { Sequence (5'-3') } \\
\text { Forward primer: }\end{array}$ & Start 294 & & 50.00 & 60.39 \\
AGCGATCGAAGAAGCAGCAA & $\begin{array}{l}\text { Stop 313 } \\
\text { Severse primer: }\end{array}$ & 1057 & 47.62 & 60.07 \\
\hline $\begin{array}{l}\text { AACGGCAGTAATTGCGTCAAC } \\
\text { Stop 1330 }\end{array}$ & $\begin{array}{l}\text { Sequence (5'-3') } \\
\text { Forward primer: } \\
\begin{array}{l}\text { ATCAAGCACAAGCTGAAGCG } \\
\text { Reverse primer: }\end{array}\end{array}$ & $\begin{array}{l}\text { Start 206 } \\
\text { Stop 225 } \\
\text { CGGCAGTAATTGCGTCAACAA } 1348\end{array}$ & 1143 & 50.00 & 59.48 \\
Stop 1328 & & 47.62 & 60.07 \\
\hline
\end{tabular}

The selected primary pairs were synthesized and used for PCR using DNA template of K7 isolate with PCR condition as follows: Pradenaturation at $95{ }^{\circ} \mathrm{C}$ for 5 min as many as 35 cycles.

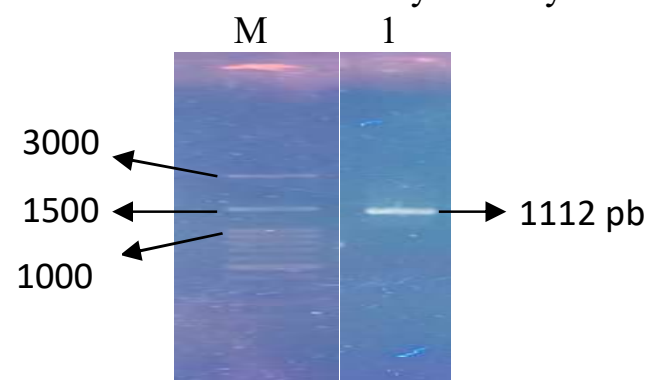

Fig.-1: The Amplification Product of glucose 6-phosphate dehydrogenase gene; M= DNA Marker; 1= K7 Isolate

The results of PCR amplification reaction were analyzed by electrophoresis and obtained amplification of PCR product generating one strand DNA fragment by sizes between 1000-1500 pb (Fig.-1). This indicates that PCR is thought to have been successful in amplifying with the size of the target gene is 1078. The PCR primer also has specific properties because generated a single strand of DNA fragments.

GGGGATTCCTGGACTTAGCGTTAGCTTCATTCAATAGCACCCTTTGGATCAATGATGATTGAGAGTACTGATTCTT GTGCTTCTTGTTCTGAACCAAAGTTGAATGTGCCAGCCTTAAATACAATATCAACACGTGTTTGCTTGGCAGCCAA ACGCTTACCTGAACGAACATAGAAAGGAACACCTTCCCAACGTGGCAAATCGAACTGTAATTCACCAGCAATGAAT GTGTTGTTCTTTGAGTCAGCAGGGACATCTGCTTCTTCCAAATATGGCTTGTAATCAGCTGTATCACCAGCACCAT ATTGTGCACGAACGAAGTATTTGTTAACTTCTTCTTCGTTATAGATCTTTAATGCATTGAATGCTGCATTCTTGGC TGCACGGATATCCTTATCGTTAAATGATTCTGGCTTTTCCATAGCTAACCAACCAACAATTTGCATTGTGTGATTT TGGATCATATCCAAAAGAGCGCCAGTAGTATCGTAGTAACCAGCACGCTCTTCAACACCTAGAACTTCAGCCAAAG TTACTTGTACGTTTTTGATATAATCCTTATTCCAAGCAGCATCAAAGATTGGGTTACCAAAACGTAATGCAGCGAT GTTTTGAACCATTTCTTTTCCAAGATAGT GGTCAATACGGAACAATTGATCATCATCAAATGCGTTTTCCAAATCA CTCTGCAATTCTTCAGCCGTGGCGTATGATGTTCCAAATGGCTTTTCAATCATCAAACGGTTGTAACCAGTGTCAG CAAGTAACCCTTCTGACTTTAGATACTTGGCAATTGTACCGAAGAAACGAGGTGCAACAGACATATAGAAGATGCG GTTGCCGTCAATGTCAAACTTAGTTGCTGCTTCTTCAATGGCTGTCTTCAAAATACCGTAAGATGCTGCATCCGTA ACATCGTGTGCGCGGTAAGAAAAATGCTCAATGAACGCTTCAGCCTGTGCTTGATCTTCAGTGAAGTCTTTAATTG ATTCACGAACCAATTGCTTAAAATCGTCATCAGTTAATTGTTGACGTGCGTTCCCAACAATAGGGGGGGGAGAAAA AAAAATtGGGAGTGAAAAAAAAGGGTCGATAGGAAAAAAAAAAAG

Fig.-2: Nucleotide Sequence gene Fragment of glucose 6-phosphate dehydrogenase

The results PCR sequencing of DNA fragment have a size of $1112 \mathrm{pb}$ (Fig-2). Meanwhile, this size is different from the target size of 1078. This shows that the glucose 6-phosphate dehydrogenase gene from $\mathrm{K} 7$ isolate is different with the glucose 6-phosphate dehydrogenase gene from bacterium used as a basis for primary design. To confirm that the fragment is glucose 6-phosphate dehydrogenase gene then a BLAST analysis against sequence of the result. The sequence of glucose 6-phosphate dehydrogenase gene was obtained and matched with nucleotides from other organisms in genebank using BLASTn (http://blast.ncbi.nlm.nih.gov/Blast.cgi) online software. The result obtained was analyzed with glucose 6- 
RASĀYAN $J$. Chem.

Vol. 14 | No. 4 |2613-2621| October- December | 2021

phosphate dehydrogenase gene from L. mesenteroides bacterium utilizing Molecular Evolutionary Genetics Analysis (MEGA-X), so, the result obtained as follows:

Table-2: BLAST Result of glucose 6-phosphate dehydrogenase gene

\begin{tabular}{|c|c|c|c|c|c|c|}
\hline Description & $\begin{array}{c}\text { Max } \\
\text { score }\end{array}$ & $\begin{array}{l}\text { Total } \\
\text { score }\end{array}$ & $\begin{array}{c}\text { Query } \\
\text { cover(\%) }\end{array}$ & E value & $\begin{array}{c}\text { Ident } \\
(\%)\end{array}$ & Accession \\
\hline $\begin{array}{c}\text { Glucose-6-phosphate } \\
\text { dehydrogenase } \\
\text { (L. suionicum) }\end{array}$ & 691 & 691 & $91 \%$ & 0.0 & $99.41 \%$ & WP_072614403.1 \\
\hline $\begin{array}{c}\text { Glucose-6-phosphate } \\
\text { dehydrogenase } \\
\text { (L. mesenteroides) }\end{array}$ & 685 & 685 & $91 \%$ & 0.0 & $98.53 \%$ & WP_036092758.1 \\
\hline $\begin{array}{c}\text { Glucose-6-phosphate } \\
\text { dehydrogenase } \\
\text { (L. mesenteroides) }\end{array}$ & 683 & 683 & $91 \%$ & 0.0 & $97.94 \%$ & WP_050892019.1 \\
\hline $\begin{array}{l}\text { MULTISPECIES: } \\
\text { glucose-6-phosphate } \\
\text { dehydrogenase } \\
\text { (Leuconostoc) }\end{array}$ & 683 & 683 & $91 \%$ & 0.0 & $97.94 \%$ & WP_002815576.1 \\
\hline $\begin{array}{c}\text { Glucose-6-phosphate } \\
\text { dehydrogenase } \\
\text { (L. mesenteroides) }\end{array}$ & 683 & 683 & $91 \%$ & 0.0 & $97.94 \%$ & WP_147008726.1 \\
\hline $\begin{array}{c}\text { Glucose-6-phosphate } \\
\text { dehydrogenase } \\
\text { (L. mesenteroides) }\end{array}$ & 682 & 682 & $91 \%$ & 0.0 & $97.94 \%$ & WP_111303602.1 \\
\hline $\begin{array}{c}\text { Glucose-6-phosphate } \\
\text { dehydrogenase } \\
\text { (Leuconostoc sp. MB7) }\end{array}$ & 682 & 682 & $91 \%$ & 0.0 & $97.94 \%$ & WP_014325243.1 \\
\hline $\begin{array}{c}\text { Glucose-6-phosphate } \\
\text { dehydrogenase } \\
\text { (L. mesenteroides) }\end{array}$ & 681 & 681 & $91 \%$ & 0.0 & $97.94 \%$ & WP_148606582.1 \\
\hline $\begin{array}{c}\text { Glucose-6-phosphate } \\
\text { dehydrogenase } \\
\text { (L. mesenteroides) }\end{array}$ & 681 & 681 & $91 \%$ & 0.0 & $97.94 \%$ & WP_146956583.1 \\
\hline
\end{tabular}

Based on Table-2 shows that the analysis result of primary design gene used the database from genebank (http://www.ncbi.nlm. nih.gov/). The sequence obtained was processed into a consensus sequence using DNA sequence analyzer software. To sequencing alignment analysis compared with genebank of National Center for Biotechnology Information (NCBI) with Basic Local Alignment Search Tool (BLAST) and Multiple-Alignment Analysis. The nucleotides sequence from sample isolate used has a very high degree of similarity with glucose 6-phosphate dehydrogenase gene (WP_072614403.1) LAB of 99.41\% by $L$. mesenteroides subsp suionicum so that nucleotides sequence is true of sequence from glucose 6-phosphate dehydrogenase gene which means that gene amplification of glucose 6-phosphate dehydrogenase has been successfully carried out.

The sequencing result of the gene generating from $\mathrm{K} 7$ isolates having a size different with size from genebank, namely $352 \mathrm{pb}$ from $1461 \mathrm{pb}$ of glucose 6-phosphate dehydrogenase gene from genebank (Fig.$3)$. Therefore, it's be equipped with sequence gene in genebank by gene alignment using CLUSTALW2 online software (https://www.ebi.ac. uk $>$ Tools $>$ msa $>$ clustalw2). So, the result was obtained intact gene sequence from glucose 6-phosphate dehydrogenase as follows: 
RASĀYAN J. Chem.

Vol. 14 | No. 4 |2613-2621| October- December | 2021

\begin{abstract}
ACAATTGCCAAGTATCTGAAGTCAGAAGGGTTACTTGCTGACACTGGTTACAACCGTTTGATGATTGAAAAGCCA TTTGGAACATCATACGCCACGGCTGAAGAATTGCAGAGTGATTTGGAAAACGCATTTGATGATGATCAATTGTTC CGTATTGACCACTATCTTGGAAAAGAAATGGTTCAAAACATCGCTGCATTACGTTTTGGTAACCCAATCTTTGAT GCTGCTTGGAATAAGGATTATATCAAAAACGTACAAGTAACTTTGGCTGAAGTTCTAGGTGTTGAAGAGCGTGCT GGTTACTACGATACTACTGGCGCCCTTTTGGATATGATCCAAAACCACACAATGCAAATTGTTGGTTGGTTAGCT ATGGAAAAGCCAGAATCATTTAACGATAAGGATATCCGTGCAGCCAAGAATGCAGCATTCAATGCATTAAAGATT TATAACGAAGAAGAAGTTAACAAATACTTCGTTCGTGCACAATATGGTGCTGGTGATACAGCTGATTACAAGCCA TATTTGGAAGAAGCAGATGTCCCTGCTGACTCAAAGAACAACACATTCATTGCTGGTGAATTACAGTTCGATTTG CCACGTTGGGAAGGTGTTCCTTTCTATGTTCGTTCAGGTAAGCGTTTGGCTGCCAAGCAAACACGTGTTGATATT GTATTTAAGGCTGGCACATTCAACTTTGGTTCAGAACAAGAAGCACAAGAATCAGTACTCTCAATCATCATTGAT CCAAAGGGTGCTATTGAATTGAAGCTTAACGCTAAGTCAGTTGAAGATGCCTTCAACACCCGCACAATCAACTTG GATTGGGCAGTATCTGATGAAGACAAGAAAAACACACCAGAACCATACGAACGTATGATTCACGATACAATGAAT GGTGACGGATCAATCTTTGCTGATTGGAACGGCGTATCAATTGCTTGGAAGTTTGTTGACGCAATTACTAGTGTT TACGAAGCAGATAAAGCTCCATTGGAGACATATAAGTCAGGGTCAACAGGTGGTGAAGCAAATGACTCACTATTA GCTATAAATGGCGATGCTTGGGTATTTAAAGGATAA
\end{abstract}

Fig.-3: The Sequence Alignment Result of glucose 6-phosphate dehydrogenase gene with using clustalw2

The sequence of the gene was alignment result glucose 6-phosphate dehydrogenase gene sequencing result with the glucose 6-phosphate dehydrogenase gene in the genebank. The alignment result from DNA fragment gene by size $1461 \mathrm{pb}$ then sequence result of the intact gene in BLAST with using BLASTn (https://blast.ncbi. nlm.nih.gov/Blast.cgi) program. After that, the sequence of glucose 6-phosphate dehydrogenase gene translated into amino acid sequence utilizing ExPASy (http://web.expasy.org/ translate/) online software for make predictions ORF and obtained of 486 amino acid (Fig.-4) with sequences as follows:

\begin{abstract}
MVSEIKTLVTFFGGTGDLAKRKLYPSVFNLYKKGYLQEHFAIVGTARQQLSDDEFKQLVRDSIKDFTEDQAQAEA FIAHF SYRAHDVTDAAS YGI LKSA IEEAATKF DI DGNRI FYMSVAPRFFGT IAKY LKSEGLLAETGYNRLMIEKP FGTSYATAEELQSDLENAFDDDQLFRIDHYLGKEMVQNIAALRFGNPIFDAAWNKDYI KNVQVTLAEVLGVEERA GYYDTTGALLDMI QNHTMQ IVGWLAMEKPES FNDKDIRAAKNAA FNALKIYNEEEVNKYFVRAQYGAGDTADYKP YLEEADVPADSKNNTFIAGELQFDLPRWEGVPFYVRSGKRLAAKQTRVDIVFKAGTFNFGSEQEAQESVLS I I ID PKGAIELKLNAKSVEDAFNTRTINLDWAVSDEDKKNT PEPYERMI HDTMNGDGSNFADWNGVS IAWKFVDAITAV YDADKAPLETYKSGSMGPEASDKLLAENGDAWVFKG
\end{abstract}

Fig.-4: The Amino Acid Sequence of glucose 6-phosphate dehydrogenase utilizing ExPASy online software

The sequence alignment of many amino acids is done using the Conesa (http://consurf.tau.ac.i1/2016/) server. The Parameters used to MSA are as follows: the homology search algorithm is CSI-BLAST with a number of literations of 3 and a cutoff E-value of 0.0001; the protein database is UNIREF-90; the alignment method is MAFFT-L-INS-i.30. from the amino acid sequence data each sequence has a different color starting from blue until purple with conservation scale is divided 3 (three) zone, namely variable, average and conserved. The results of MSA with Conseq server (Fig.-5).

Figure- 5 shows that from 481 amino acids, there are 80 amino acids were predicted as functional (f) zone that is very conservative to reaction with enzymes because amino acid has an active side outside meanwhile 42 amino acids were predicted as conservative region who can reaction with enzymes because have an active side inside (s). If the environment is water, then $\mathrm{f}$ more characteristic as hydrophilic to forming a network of hydrogen bonds that contributed to three-dimensional structure stabilization meanwhile s more characteristic as hydrophobic. The exposed (e) and buried (b) show the residue is outside and inside appropriate with network algorithm of amino acids composition as many as 311 and 170 amino acids respectively.

Figure-6 shows that homology result of sample isolate tested with protein database of UNIREF-90, the sample isolate having similarity of amino acid composition 441 amino acids with UniRef90_P11411_1_486 protein by name description is glucose-6-phosphate 1-dehydrogenase which derives from $\bar{L}$. mesenteroides bacterium because it has been reported to have similar glucose-6-phosphate dehydrogenases. ${ }^{11}$ The interesting from the result is amino acids composition were obtained very different compared with protein database of 40 amino acids, namely as follows: LTGGGDKANDDAVEDDANNSATDASFLADG 
RASĀYAN J. Chem.

Vol. 14 | No. 4 |2613-2621| October- December | 2021

TNSATMPSKA with Eval of 2.2e-297 it means that the sample variable is very significant and protein database to glucose-6-phosphate-1-dehydrogenase. It's still which from L. mesenteroides bacterium.

\section{ConSurf Results}

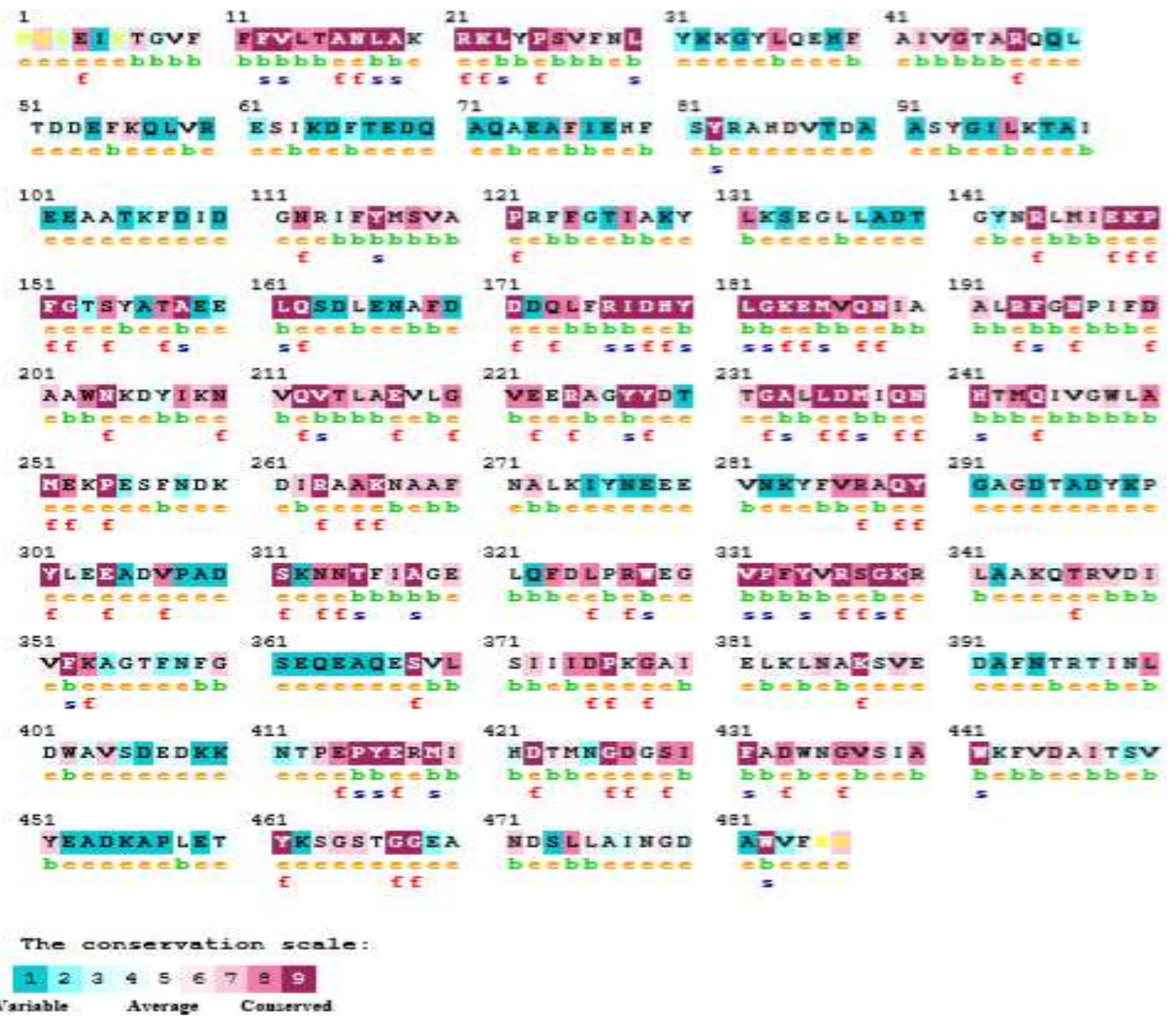

Fig.-5: The Results of MSA with Conseq server of glucose 6-phosphate dehydrogenase gene

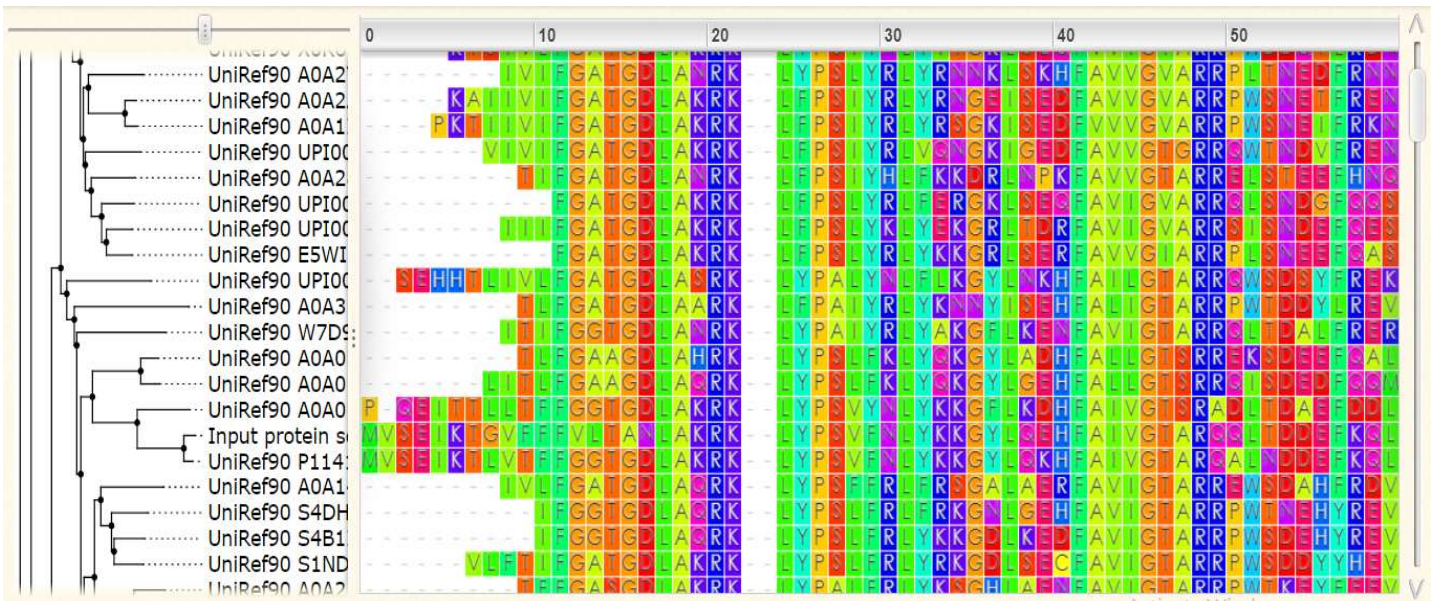

Fig.-6: The Homology of Sample with Protein Database

The multiple alignment analysis against a sequence of glucose 6-phosphate dehydrogenase gene from $\mathrm{K} 7$ sample with using Molecular Evolutionary Genetics Analysis (MEGA-X) to determine closest kinship from sample through Phylogenetic tree and obtained result from LAB isolate of K7 sample. The Multiple alignment analysis result from phylogenetic tree is glucose 6-phosphate dehydrogenase of $\mathrm{K} 7$ have closest kinship L. suionicum bacterium (Fig.-7). 
RASĀYAN J. Chem.

Vol. 14 | No. 4 |2613-2621| October- December | 2021

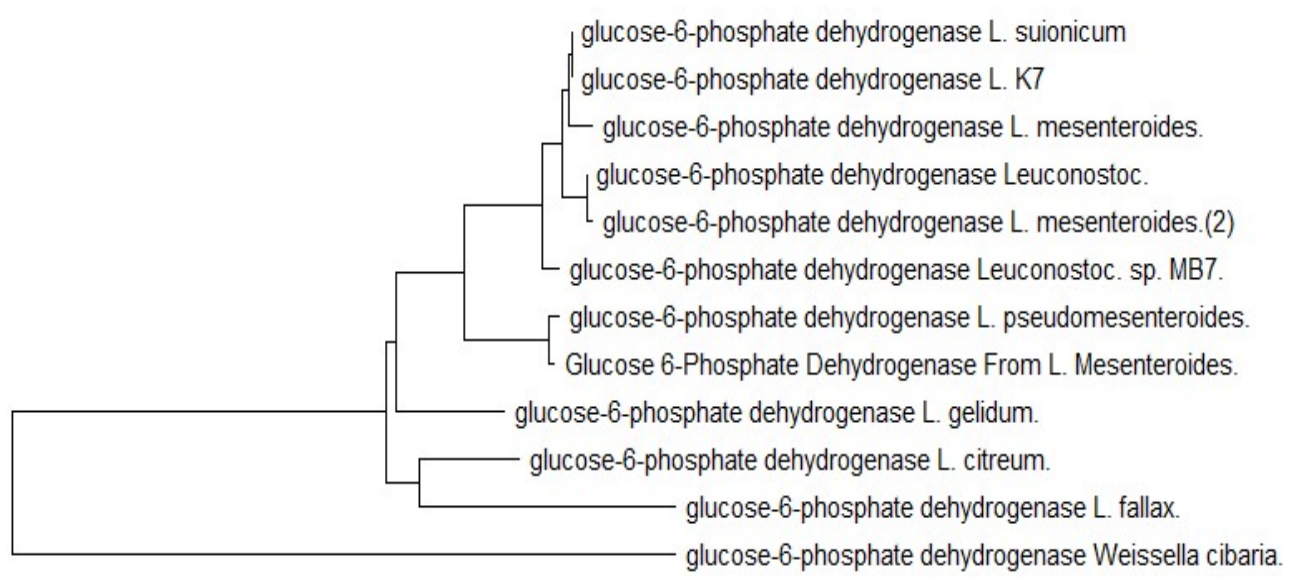

Fig.-7: The Phylogenetic Tree of glucose 6-phosphate dehydrogenase from K7 isolate

The prediction of 3D structure from protein modeling was done after active side is already known from MSA result with Conseq server. The prediction of 3D structure from protein modeling by enter the amino acids with same way on star a new modeling project (https://swissmodel.expasy.org/interactive) table from SWISS-MODEL (https://swiss model.expasy.org/) server. The results of modeling prediction are as follows:

Figure- 8 shows that the isolated sample with an arrow to the right $\beta$-strand, rounded rectangle for $\alpha$-helix structure. The white character in the box for residue in contact with yang $\mathrm{Mg}^{2+}$ ligand. The $\alpha$-helix structure in form spiral and chain twist of amino acids and $\beta$-sheet in form sheets composed of amino acid chains which are tied to each other through hydrogen or thiol bonds $(\mathrm{S}-\mathrm{H})$. The attractive forces between the amino acids in a protein sequence caused main structure twists, loops, and folding (Fig.-9).

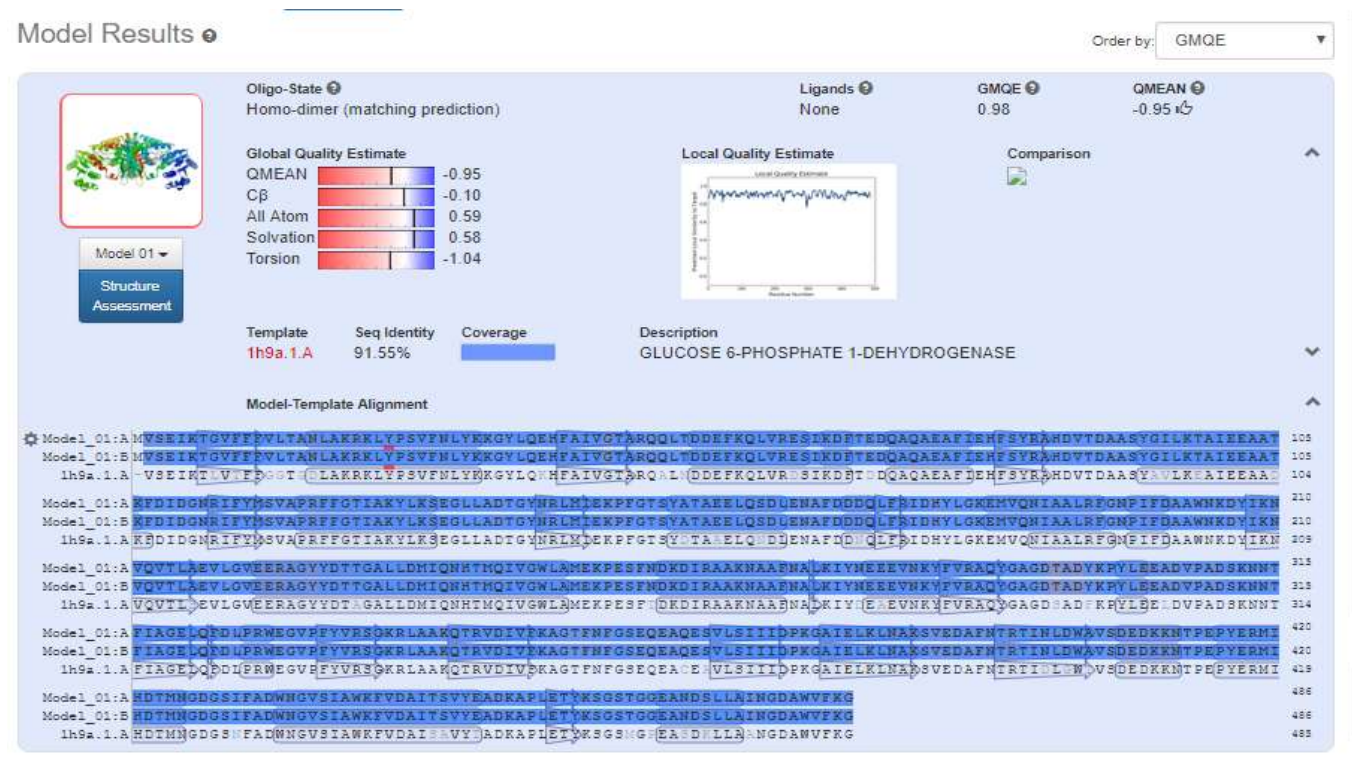

Fig.-8: The Model Template Alignment of isolate and template (1h9a.1.A) by SWISS-MODEL.

The form of enzymes prediction generated can form spiral, helix, and sheets. This form is called secondary structure. The protein structure usually is a polypeptide folded in 3D shape with the branches of the polypetide chain are arranged close to each other. This structure of peptide and hydrogen bonds between $\mathrm{N}-\mathrm{H}$ and $\mathrm{C}=\mathrm{O}$ group acts as a backbone structure. The secondary structure of a protein is the local $3 \mathrm{D}$ structure of various amino acid sequences in protein which is stabilized by hydrogen bonds because the external electron acceptors have the leverage to end products. ${ }^{12}$ The $3 \mathrm{D}$ modeling predictions of sequence identification results in target protein isolate and template (1h9a.1.A) have in the similarity of $91.55 \%$ by 
RASĀYAN J. Chem.

Vol. 14 | No. 4 |2613-2621| October- December | 2021

glucose 6-phosphate dehydrogenase which has properties as a homo dimer. Homo dimers are chemical compounds that consist of two identical or similar molecules and bonded to the same two molecules. The complex structure contained in proteins has ligands, among others: $2 \mathrm{x}$ NAP with formula $\left(\mathrm{C}_{21} \mathrm{H}_{28} \mathrm{~N}_{7} \mathrm{O}_{17} \mathrm{P}_{3}\right)$ and 2xNADP (Nicotinamide-Adenine-Dinucleotide Phosphate).

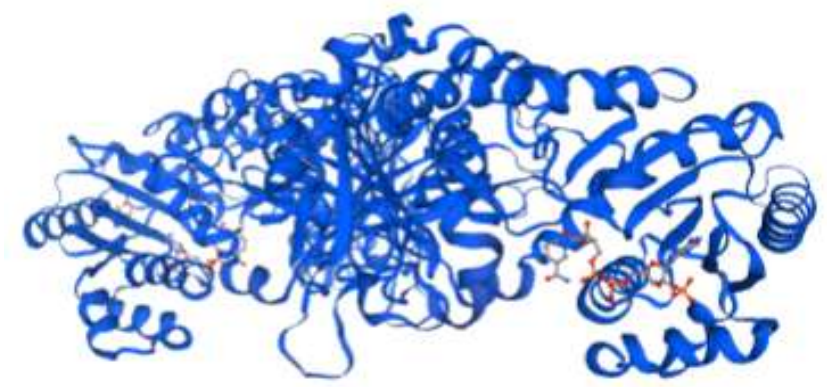

Fig.-9: The 3D Model Prediction of glucose 6-phosphate dehydrogenase

CONCLUSION

The gene fragments lactic acid bacteria of L. mesenteroides strain K7 from Kelengkeng fruit have been characterized by a length of $1112 \mathrm{bp}$. The similarity percentage of $99.41 \%$ with glucose 6-phosphate dehydrogenase. The modeling structure from protein target with SWISS-MODEL server utilizing in silico modeling obtained prediction results target protein isolate and template (1h9a.1.A) have in the similarity of $91.55 \%$ by glucose 6-phosphate dehydrogenase.

\section{ACKNOWLEDGEMENT}

This study was financially supported by Directorate research and community service or Direktorat penelitian dan pengabdian Masyarakat (DPPM) Universitas Islam Indonesia, Yogyakarta, Indonesia.

\section{REFERENCES}

1. A. Akhdiya, A. T. Wahyudi, A. Munif, L. K. Darusman, HAYATI Journal of Biosciences, 21(4), 187 (2014), https://doi.org/10.4308/hjb.21.4.187

2. C.R. Viridiana, D.A. Lidia, A. P. Lovillo, H. S. Humberto, Reference Module in Food Science, (2018), https://doi.org/10.1016/B978-0-08-100596-5.22601-2

3. L. Mele, M. L. Noce, F. Paino, T. Regad, S. Wagner, D. Liccardo, G. Papaccio, A. Lombardi, M. Caraglia, V. Tirino, V. Desiderio, F. Papaccio, Journal of Experimental \& Clinical Cancer Research 38,160(2019), https://doi.org/10.1186/s13046-019-1164-5

4. D.R. Nataningtyas, T.J. Raharjo, E. Astuti, Indonesian Journal of Chemistry, 19(3), 565(2019), https://doi.org/10.22146/ijc.34152

5. H. Hidayat, W. Haryadi, T.J. Raharjo, Biodiversitas Journal of Biological Diversity, 21(7) (2020), https://doi.org/10.13057/biodiv/d210737

6. H. Wijaya, F. Hasanah, Biopropal Industri, 7(2), 83(2016)

7. W. Xu, F. Lu, H. Wu, W. Zhang, C. Guang, Process Biochemistry, 96, 194(2020), https://doi.org/10.1016/j.procbio.2020.05.014

8. H. Choi, Y. W. Kim, I. Hwang, J. Kim, S. Yoon, Food Chemistry, 134(4), 2208(2012), https://doi.org/10.1016/j.foodchem.2012.04.047

9. S. Jayanti, S. H. Bintari, R. S. Iswari, Unnes Journal of Life Science, 4(2), 79(2015)

10. R. Manej, Laboratory Roche Diagnostic Research, 23(32), 45(1991)

11. Q. Li, F. Yang, R. Liu, L. Luo, Y. Yang, L. Zhang, H. Liu, W. Zhang, Z. Fan, Z. Yang, L. Cui, Y. He, PLoS ONE, 10(9), e0138038 (2015), https://doi.org/10.1371/journal.pone.0134593

12. S.Q. Liu, Reference Module In Food Sciences, 1-6 (2016), https://doi.org/10.1016/B978-0-08-100596$\underline{5.00859-3}$

[RJC-6287/2020] 